\title{
Characterizing Cumberland Fluted Biface Morphology and Technological Organization
}

\author{
Jesse W. Tune \\ Department of Anthropology, Fort Lewis College, Durango, Colorado 81301 \\ [jwtune@fortlewis.edu]
}




\section{Introduction}

Since originally defined by Thomas M. N. Lewis in 1954, Cumberland fluted bifaces have received long-term and widespread interest. They are frequently referenced in discussions of Paleoindian chronologies (Anderson and Sassaman 2012; Anderson et al. 2010; 2015; Broster et al. 2013; Driskell et al. 2012; O’Brien et al. 2001, 2014) and potential Younger Dryas (YD)related human adaptations (Anderson et al. 2011; Meeks and Anderson 2012). However, questions still remain regarding the production, use, and timing of Cumberland bifaces in relation to other Paleoindian technologies. While there is an extensive body of literature devoted to understanding other fluted biface technologies (e.g., Amick 1999; Bradley et al. 2010; Gingerich 2013; Waters et al. 2011), research related to Cumberland has been extremely limited. Nearly all previous studies of Cumberland technology were conducted on datasets of fewer than 20 specimens (Boldurian and McKeel 2011; Cambron and Hulse 1961; Jolly 1972; Morse et al. 1964). Thus, until there is a thorough understanding of what Cumberland is, discussions related to its chronological association with other biface types, technological organization, and relevance to YD-related adaptations, will remain speculative.

Cumberland represent the instrument-assisted fluted horizon in the North American Midsouth, and though currently undated, are assumed to be generally contemporaneous with the earliest part of the YD (Anderson 2004; Anderson and Sassaman 1996; Anderson et al. 2010, 2015; Bradley et al. 2008; Broster et al. 2013; Ellis and Deller 1997; Fiedel 1999; Goodyear 1999; Meeks and Anderson 2012; Meltzer 2009; Tankersley 1990, 1996). While these bifaces are prevalent throughout the Midsouth, they have only been recovered from surface or disturbed contexts (Anderson et al. 2010; Anderson et al. 2011; Goodyear 1999). Jolly's (1972) study comparing Cumberland and Clovis fluted biface technology in the Middle Tennessee River Valley, though 30 years old, is still the most detailed discussion of the Cumberland biface reduction sequence. However, the small sample size $(n=14)$ provides limited support for his interpretation of Cumberland technology. Although Bell (1960) states the Cumberland toolkit consists of various unifacial tools, there are currently no known discrete Cumberland assemblages.

The overall objective of this study is to identify, and offer potential explanations for, variability within Cumberland biface technology. The research presented here is the first to comprehensively address the question, "What is Cumberland?" from the perspective of technological organization, and incorporates previous studies of geographic distribution and chronology with new morphological and technological data. One way to link lithic artifacts to behavioral adaptations is to reconstruct how hunter-gatherers organized their lithic technologies (Binford 1979; Kuhn 1995; Shott 1986; Torrence 1983). Investigating the organization of technology allows us to view technology as a set of behaviors related to human adaptation rather than a set of objects related to a production procedure (Nelson 1991). As such, studying how bifaces were made, hafted, used, refurbished, and discarded can offer valuable insight into how Cumberland technology was organized (Kuhn, 1995; Nelson, 1991). In turn, the life histories, as it were, of Cumberland bifaces can be used to support inferences about behavioral adaptations in the Midsouth during the late Pleistocene (Binford 1979; Nelson 1991).

\section{Geographic Distribution}


Unlike most other diagnostic point types, there is not a type-site for Cumberland flutedbifaces. Rather, the genesis of Cumberland as a type is derived from the dense concentration of bifaces recovered along the Cumberland River in middle Tennessee during the early twentieth century. Lewis (1954) coined the name Cumberland to describe a large, thick lanceolate flutedbiface, which he saw as similar to Clovis and found throughout the Cumberland River Valley. The core geographic distribution of Cumberland encompasses much of the area between the Tennessee and Ohio Rivers (Figure 1) (Anderson et al. 2010; Justice 1987). The conflation of typological names, such as with Barnes in the Great Lakes region, may explain the identification of some Cumberland-like bifaces across a larger territory (e.g., Bradley et al. 2010; Justice 1987; White 2006). Notably, the Midsouth is also characterized by an abundance of high-quality cherts (Amick 1987; Parish 2011, 2013). The majority of Cumberland bifaces are made from Fort Payne and St. Louis cherts, which naturally occur in tabular and cobble forms from northern Alabama to central Kentucky.

Data available in PIDBA and state surveys suggest that people using Cumberland fluted bifaces had a predilection for major river valleys in the Midsouth, similar to Clovis (Anderson 2004; Anderson et al. 2010; Barker and Broster 1996; Breitburg and Broster 1994; Broster and Norton 1996). Based on Clovis data, Miller (2011) suggests that rather than sampling or population biases, the distribution of fluted bifaces in the Midsouth reflects a land-use strategy focused on the intersection of rivers, physiographic boundaries, and toolstone sources. It is reasonable to assume that this pattern holds true for Cumberland as well, given the similarities in technological organization between the two types (Tune 2016).

\section{**** 2-COLUMN FITTING ***}

Figure 1. Generalized core distribution of Cumberland fluted bifaces and sites referenced in text.

Though Cumberland bifaces are dispersed throughout the Midsouth, relatively high densities have been documented in certain areas that may represent habitual-use sites. These locations may be similar to aggregation sites associated with Clovis macrobands (Anderson 1990, 1996; Smallwood 2012), and may reflect a post-Clovis continuation of macroband aggregation behaviors. The Sandy Springs site, in southern Ohio, is near the northern extent of Cumberland distribution and is located in close proximity to a saline spring (Seeman et al. 1994; Tankersley 1994). At least 15 Cumberland bifaces have been documented from the site, which has limited evidence for on-site biface reduction and a high percentage of finished bifaces made from non-local raw materials (Aagesen 2006; Seeman and Prufer 1982; Seeman et al. 1994; Tankersley 1989).

The Parris Collection and Heaven's Half Acre may represent habitual-use sites near the southern extent of Cumberland distribution. The Parris Collection primarily comes from multiple sites in Hardin County, in south-central Tennessee (Tune et al. 2015). Extensive research by noted avocational archaeologist Jim Parris identified a series of fluted biface sites concentrated on remnant levees of the Tennessee River. Heaven's Half Acre represents a series of fluted biface sites near the Tennessee River in northern Alabama. Since the 1950s avocational archaeologists have recovered large numbers of Cumberland and other fluted biface forms from the margins of geomorphic depressions that may have been wet season ponds during the late Pleistocene (Futato 1996; King 2007). Both the Parris Collection and Heaven's Half Acre assemblages are characterized by impact damage and basal fragments made on locally available raw materials, and likely reflect discard behaviors and possibly toolkit maintenance activities. 


\section{Chronological Considerations}

Buried and datable Paleoindian sites are notoriously rare in the Midsouth (e.g., Miller and Gingerich 2013), and at this time Cumberland bifaces have only been recovered from surface contexts and palimpsest components containing multiple biface types. This situation has prevented Cumberland from being directly dated. Technological similarities to other well-dated, and presumably coeval, biface types in adjacent regions, as well as stratigraphic associations in the Midsouth support a post-Clovis chronology. Based on widely accepted technological chronology, the emergence of instrument-assisted fluted technologies across the continent postdate Clovis and generally corresponds to the earliest part of the YD (Anderson et al. 2015; Anderson et al. 2010; Bradley et al. 2008; Ellis and Deller 1997; Fiedel 1999; Goodyear 1999, 2010; Meltzer 2009; Tankersley 1990, 1996). Technologically similar Folsom fluted bifaces have been securely dated throughout the Plains and Southwest to $10,700-10,390{ }^{14} \mathrm{C}$ yr BP (12,680-12,260 cal yr BP) (Frison and Stanford 1982; Hill 2001; Hill and Hofman 1997; Hofman 1995; Meltzer 2006), and correspond well with the expected range of Cumberland in the Midsouth.

Assuming that Clovis immediately precedes instrument-assisted fluting in the Midsouth, as it does in other regions, then it is possible to establish a maximum age for Cumberland, which may also be contemporaneous with other regional fluted technologies such as Redstone. Relying on charcoal-based radiocarbon ages, the age of Clovis in the greater Southeast matches that of other regions, and ranges from $10,980 \pm 75$ to $10,915 \pm 30{ }^{14} \mathrm{C}$ yr BP $(12,860 \pm 90$ to $12,760 \pm 30$ cal yr BP) (Brose 1994; Goodyear 2013; McAvoy and McAvoy 1997; Waters et al. 2009). Therefore, Cumberland is assumed to occur after ca. 12,800 cal yr BP.

Cumberland bifaces (as well as Quad, Beaver Lake, and Dalton) were recovered from the lowest cultural deposits of Dust Cave, northern Alabama (Driskell 1994, 1996; Sherwood et al. 2004). A heavily reworked Cumberland biface and a Cumberland-like distal biface fragment were recovered from the basal components (Driskell 1994, 1996; Hollenbach and Walker 2010; Sherwood et al. 2004). The precise stratigraphic sequence of the Paleoindian bifaces at Dust Cave is unclear, as multiple types co-occur within the same deposits. Dalton, however, generally occurs above other Paleoindian forms (Driskell et al. 2012; Sherwood et al. 2004), and thus, may provide a minimum age for Cumberland. Eight radiocarbon ages on dispersed charcoal in the lowest Quad/Beaver Lake/Dalton component (Zone U) range from 10,500 \pm 60 to 10,310 \pm 60 ${ }^{14} \mathrm{C}$ yr BP $(12,430 \pm 120$ to $12,140 \pm 140 \mathrm{cal}$ yr BP) (Sherwood et al. 2004). As such, ca. 12,100 cal yr BP may represent a minimum age for Cumberland.

The Phil Stratton site, in Kentucky, has been presented as an intact Cumberland site dating older than 14,000 cal yr BP (Gramly 2008, 2009, 2012, 2013, 2015). However, reanalysis of the existing assemblage and new excavations have documented significant contextual problems with the assemblage and proposed dates (Tune and Melton 2013). Of the 42 identifiable bifaces, only six are Cumberland. The remaining 36 are Archaic, Woodland, and Mississippian. Based on the diagnostic biface assemblage, the Phil Stratton site does not represent a pure Cumberland site. Rather, the site appears to have been extensively re-occupied beginning in the late Pleistocene and continuing throughout the entire Holocene.

In 2013 I directed an excavation of the site to study the stratigraphy and potentially recover additional artifacts. The 2013 excavation units were placed immediately adjacent to the previous excavation blocks to correlate the geologic profiles and evaluate previous 
interpretations of the site (Figure 2). Two units were specifically placed adjacent to a "witness section that was set aside for future investigators" (Gramly 2013:143). The 2013 excavation documented shallow, deflated deposits that are extensively disturbed by tree roots, bioturbation, and agricultural processes.

\section{*** 2-COLUMN FITTING ***}

Figure 2. Phil Stratton site excavation blocks and distribution of identifiable bifaces. Adapted from Gramly 2013.

Two geologic units were recorded in 2013 at the southern-most edge of the site where deposition is greatest (Figure 3). The upper Unit $2(0-25 \mathrm{~cm})$ is a brown $(10 \mathrm{YR} 4 / 4)$ silty clay loam with subangular blocky structure, few small roots, abundant iron manganese accumulations, and an abrupt wavy boundary. Unit 2 is composed of eolian sediments redeposited from the erosion of the upper hill slope. The lower Unit $1(25+\mathrm{cm})$ is an oxidized brown clay loam (7.5YR 4/6) with few iron manganese accumulations, common bioturbation features, and an abrupt (erosional), wavy boundary. Unit 1 represents a clay residuum formed from the weathering of the limestone bedrock and is commonly exposed throughout the surrounding area due to erosion by intensive agricultural practices. In some areas of the site Unit 2 is covered by up to $25 \mathrm{~cm}$ of recently redeposited fill consisting of a mixture of both Units 1 and 2. Artifacts are deposited throughout Unit 2, and occasionally intrude into Unit 1 through root molds and animal burrows. Artifacts are also present in the redeposited overburden.

\section{*** 1.5-COLUMN FITTING ***}

Figure 3. Generalized profile of the Phil Stratton site with the relative depths of OSL ages reported by Gramly (2013) correlated with the stratigraphic profile documented in the 2013 excavation.

Gramly (2012) contends the Cumberland occupation at the Phil Stratton site predates 14,000 cal yr BP based on a series of optically stimulated luminescence (OSL) dates. A critical review of the published literature, however, clearly indicates that such early dates do not correlate with the artifact-bearing deposits. As such, a calibration curve was constructed to correlate the OSL ages with the artifact-bearing deposit (Gramly 2013, 2015). The OSL calibration curve is based on two unsupported assumptions. First, the modern ground surface at the Phil Stratton site is assumed to be equivalent in age to the end of Peoria Loess deposition, which according to Gramly $(2013,2015)$ occurred at 12,800 cal yr BP. Peoria Loess deposition has been well-studied throughout the Central Plains and Midwest and its terminus is dated to 16,000-12,000 cal yr BP (Bettis et al. 2003; Johnson and Willey 2000; May and Holen 2003; Muhs et al. 1999, 2001, 2008). Second, such a calibration also assumes a constant rate of deposition has occurred without any erosional episodes. However, the Phil Stratton site is located on a highly eroded landform that has been subjected to intense agricultural plowing since the early nineteenth century (Phil Stratton personal communication). Moreover, a major unconformity representing another episode of erosion is clearly visible at the contact of geologic Units 1 and 2 (Figure 4). Thus, the variable rate of deposition and erosion, as well as the unsupported age of the ground surface refute any interpretations drawn from the OSL calibration curve for the Phil Stratton site. 


\section{*** 2-COLUMN FITTING ***}

Figure 4. Stratigraphy documented during the 2013 excavation. East wall of Unit S21/E17 showing abrupt boundary between geologic Units 1 and 2.

Furthermore, the OSL ages likely represent pedogenesis rather than the timing of deposition because pedogenic processes mix grains of various ages (Bateman et al. 2007a, 2007b). Pedogenesis is known to compromise the results of OSL dating, specifically in upland geomorphic settings with thick, weathered argillic horizons (Ahr et al. 2013), such as at Phil Stratton. Ahr and colleagues studied the effects of pedogenesis in sandy sediments of upland sites in Texas and found that "pedogenic mixing of particles of various apparent ages, and... changes in environmental dose rate due to weathering" skewed the ages of those samples (Ahr et al. 2013:221). As a result, the OSL ages represent "apparent age estimates rather than true depositional ages" (Ahr et al. 2013:14). Because Phil Stratton is in a similar geomorphic setting, and similar pedogenic processes have affected the sediments, the OSL ages there also likely reflect pedogenesis rather than deposition. Thus, at this time the OSL ages from Phil Stratton do not provide an accurate age of Cumberland occupation.

\section{Materials and Methods}

To identify and interpret variability in Cumberland technology, over 900 Cumberland fluted bifaces were examined. While it is very likely that fluted and unfluted Cumberland bifaces were part of the same technological system, the lack of context and typological similarities to other late Pleistocene biface forms (e.g., Beaver Lake), preclude the analysis of unfluted specimens in this study. In time fluted and unfluted Cumberland bifaces may be recognized as part of the same technological system that also includes Beaver Lake, similar to Folsom and Midland bifaces (Amick 1995; Hofman 1992; Jennings 2012; Meltzer 2006). Primary data collected from collections throughout the Tennessee and Ohio River Watersheds, as well as data from PIDBA, were analyzed to study quantitative and qualitative attributes of Cumberland biface morphology (Table 1). The PIDBA data were previously collected by regional Paleoindian specialists. In turn, the combined datasets were used to study technological elements related to artifact life histories. Assessing biface production, use, reuse, and discard, facilitates interpretations of technological organization and may help explain variability (Andrefsky 2010). Finally, inferences about settlement strategies were made based on the organization of technological elements.

Table 1. Cumberland collections included in analyses.

\section{*** 1.5-COLUMN FITTING ***}

While intact and dateable late Pleistocene archaeological sites are rare in the Midsouth, exceptional fluted biface survey data has been compiled (Anderson 2004; Anderson et al. 2010; Goodyear 1999; Miller and Gingerich 2013). Potential biases and limitations are known for PIDBA datasets and include incomplete data, sample inconsistency, site formation processes, and ground cover (see Anderson et al. 2010 and Prasciunas 2011 for a detailed discussion of potential biases). Given these limitations, PIDBA datasets are still widely accepted to model regional human behaviors (Anderson and Gillam 2000; Anderson et al. 2011; Lanata et al. 2008; Meeks and Anderson 2012; Miller 2011; Shott 2013; Smallwood 2012; Smallwood et al. 2015). 
Due largely to their relative scarcity, Cumberland bifaces are known by artifact collectors and PIDBA data contributors as one of the more commonly reproduced biface types. Unfortunately, there is often no easy way of determining modern reproductions from archaeological specimens when they are part of a larger collection (whether public or private). This reality, as well as the broader issues of working with private collections, has been the subject of much debate and recently highlighted in the discussion "Pros and Cons of Consulting Collectors" in the SAA Archaeological Record, Volume 15, No. 5. Throughout the research presented here, every effort was made to eliminate artifacts with questionable provenience. Furthermore, in situations where I thought the inclusion of an artifact into this research would directly contribute to its monetary value, I removed it from my datasets.

\subsection{Methods for Characterizing Morphology}

Assessing biface morphology is a productive way to identify and document the range of variability within biface technologies. The morphological study presented here is based on primarily analysis of 216 finished Cumberland fluted bifaces (Table 2). An additional 691 finished Cumberland bifaces record by other researchers and documented in PIDBA were also included in this study. All maximum measurements and morphological ratios used in this study are documented only on complete specimens. Basal width, waist width, depth of basal concavity, and depth of basal concavity-to-basal width are documented from basal fragments and complete specimens.

I characterize Cumberland biface morphology using a standard set of metric variables and morphological ratios (Eren et al. 2011; Jennings 2013; Morrow and Morrow 1999; Smallwood 2012; Thulman 2006). For each finished biface, I recorded the maximum length, maximum width, maximum thickness, basal width, waist width, face-angle, flute length and width (when possible), inner flute thickness, depth of basal concavity, weight, presence/absence edge grinding, and blank form (when possible). I calculated morphological ratios such as length-towidth, width-to-thickness, depth of basal concavity-to-basal width, and lateral indentation index (LII) for each biface. Presumably the most standardized attributes reflect the elements most critical to the overall technological system. As such, I calculated a coefficient of variation (CV) for all attributes as a way to measure relative standardization (Eerkens and Bettinger 2001). Coefficient of variation provides a statistical technique to assess standardization between samples by comparing standard deviation to the mean (Eerkens and Bettinger 2001). The smaller a $\mathrm{CV}$ value is, the more standardized the sample is.

Table 2. Cumberland bifaces included in analyses.

\section{*** 1.5-COLUMN FITTING ***}

\subsection{Methods for Studying Technological Organization}

To understand how Cumberland bifaces were made, used, reworked, and discarded I recorded flaking pattern, basal grinding, thermal alteration, fluting elements, and post-fluting reduction, as well as patterns in fracture types, reworking, and abandonment. These attributes reflect elements of provisioning strategies as they are related to organization (Pitblado 2003).

While patterns in the nature and frequency of fracture types potentially reflect functional behaviors, patterns of reworking and repair also reflect provisioning strategies; thus, I 
documented type and frequency of reworking. I calculated technological ratios such as average grinding length-to-maximum length and average flute length-to-maximum length for complete bifaces. I documented the apparent reason for abandonment to understand why and when Cumberland bifaces were deemed no longer useful.

\subsection{Methods for Interpreting Settlement Strategies}

While the interpretation of Cumberland settlement strategies presented here is framed in terms of provisioning strategies - provisioning places versus provisioning individuals - it is important to emphasize that this is not a dichotomy, but rather represents a continual range of variation (Kuhn 1990). Furthermore, it should be noted that provisioning strategies are not static, but are flexible enough to be altered to meet seasonal or fluctuating demographic needs (Binford 1980). This is particularly relevant when one considers the evidence that late Pleistocene populations in the Southeast were likely regularly aggregating in macroband groups (Smallwood 2012). Though Smallwood (2012) focuses specifically on Clovis settlement patterns, it is likely that Cumberland settlement patterns were similar, especially given the similarities in technological organization between the two technologies (Tune 2016). Furthermore, large Cumberland assemblages from sites such as Sandy Springs (Aagesen 2006; Seeman and Prufer 1982; Seeman et al. 1994; Tankersley 1989), and collections such as the Parris Collection (Tune et al. 2015) and Heaven's Half Acre (King 2007) may provide evidence of potential Cumberland aggregation behaviors similar to Clovis.

Residentially organized strategies are marked by frequent moves between short-term residential camps with continual transport of tools in environments where resource distribution is unknown or unpredictable (Kuhn 1992). To ensure tools are available when they are needed, technology is structured around the concept of provisioning individuals with "personal gear" (Binford 1979). As such, bifaces are expected to be used to the point of exhaustion and exhibit extensive rejuventation when they are discarded, which results in a high ratio of complete to broken bifaces (Table 3, Pitblado 2003). Conversely, a logistically organized strategy is structured around the provisioning of specific places on the landscape. Environments where resource distribution is known or predictable, and future needs can be expected, favors a logistically organized strategy (Kuhn 1992). As bifacial tools become dull or break, they are replaced rather than reworked resulting in a relatively low complete-to-broken biface ratio (Pitblado 2003).

Table 3. Expected characteristics of provisioning strategies.

\section{*** 1-COLUMN FITTING ***}

\section{Characterizing Cumberland}

\subsection{Cumberland Biface Morphology}

Cumberland bifaces exhibit standardized basal elements and greater variation in length. The least variable attributes of Cumberland biface morphology are maximum width $(23.83 \mathrm{~mm})$, basal width $(20.95 \mathrm{~mm})$, and inter flute thickness $(5.43 \mathrm{~mm})$ with CVs less than 20 percent $(\%)$ (Table 4). Maximum thickness $(7.58 \mathrm{~mm})$, and waist width $(19.85 \mathrm{~mm})$ are the next most standardized attributes, with CVs less than 25\%. The average maximum length is $75.07 \mathrm{~mm}$, 
with a $\mathrm{CV}$ of $33 \%$. The average basal concavity depth is $3.17 \mathrm{~mm}$ with a $\mathrm{CV}$ of $51 \%$, while the ratio of basal concavity depth-to-basal width has a $\mathrm{CV}$ of $67 \%$.

Based on morphological ratios, Cumberland bifaces are over three times longer than they are wide; likewise, width-to-thickness is approximately 3.25:1. Waist width-to-basal width and the lateral indentation index (LII) both have a CV less that 30\%. Waist width-to-maximum width has a CV of $31 \%$. These morphological ratios reflect the characteristically "waisted" shape of Cumberland bifaces, and further reflect standardization in hafting methods.

Face-angle was recorded for 80 complete and finished specimens. Face-angle quantifies the expansion of the lateral edges of bifaces by measuring the angle of the lateral edges to the base (Roosa and Ellis 2000). Essentially this measurement further quantifies the relationship between basal and maximum width. Therefore, laterally reworked bifaces should be more variable, while distally reworked bifaces should be more standardized. The average face-angle of Cumberland bifaces is 92.60 degrees, and is the least variable attribute $(\mathrm{CV}=4 \%)$. The overall morphological characteristics indicate that Cumberland bifaces were primarily reworked from the distal end. This characteristic is similar to other Paleoindian point types such as Folsom, which typically exhibit little resharpening of the lateral margins and are reworked from the tip (Ahler and Geid 2000).

Table 4. Morphological characteristics of Cumberland bifaces.

\section{*** 1.5-COLUMN FITTING ***}

\subsection{Cumberland Biface Technology}

This study focuses on technological attributes that are related to basal treatment and flaking techniques. Cumberland bifaces, on average, are ground to $25.47 \mathrm{~mm}$ from the base, or $35 \%$ of the total length (Table 5). The average flute length is $46.32 \mathrm{~mm}$, or $60 \%$ of the total length. The average flute width is $11.49 \mathrm{~mm}$. Average flute length, however, is considerably variable $(\mathrm{CV}=45 \%)$, while flute widths are more standardized $(\mathrm{CV}=29 \%)$. The variation documented in flute dimensions further suggests that Cumberland bifaces were distally reworked, with only minor modification to the lateral edges after completion. Basal beveling occurs in $49 \%$ of Cumberland bifaces examined, while $51 \%$ are not beveled. This characteristic is likely related to basal preparation prior to fluting, which has also been previously noted on Clovis bifaces (Broster et al. 2013; Collins 1990; Waters and Jennings 2015; Waters et al. 2011).

Table 5. Technological characteristics of Cumberland bifaces.

*** 1.5-COLUMN FITTING ***

Collateral flaking is the dominant flaking pattern (81\%) documented on complete, finished specimens. This is an important aspect of Cumberland technology due to the creation of a midline ridge typically running the length of the biface. Interestingly, five percent of Cumberlands studied exhibit occasionally overface flaking similar to Clovis bifaces. These overface flake scars are likely remnants of percussion flaking during initial bifacial reduction. Overface flaking does not appear to be an intentional reduction method for the production of Cumberland bifaces.

Thermal alteration, identified by the presence of potlid fractures, occurs in low frequency $(11 \%)$ and was likely not related to the production process. Thermal alteration is only identified 
on biface fragments. Many of the potlid fractures are located along the margins of transverse breaks, suggesting that heating occurred after they were discarded. Other specimens, such as one of the bifaces from the Phil Stratton site, explosively fractured into multiple fragments that have been refitted indicating thermal alteration occurred at the time, or after, the biface was discarded.

\subsection{Cumberland Biface Reduction Sequence}

Of the complete Cumberland bifaces available for analysis, 93\% $(n=79)$ exhibited a biconvex transverse cross section. The remaining seven percent $(n=6)$ were plano-convex in cross section. This pattern appears to be related to initial blank form used for the production of bifaces. The overwhelming majority $(89 \% ; \mathrm{n}=76)$ of complete bifaces were made from bifacial blanks. Just $11 \%(\mathrm{n}=9)$ of the complete bifaces, including all plano-convex specimens, were made on flakes. Bifaces made on flake blanks were identified based on the remnants of the original ventral face of the flake or pronounced longitudinal curvature.

Preforms were initially shaped into a rowboat form with convex lateral edges and a straight to convex base. Initial reduction and shaping was completed with large, random percussion flake removals (Figure 5a, b). The convex lateral edges typically exhibit little or no waisting. Early in the reduction sequence flaking may extend across the midline, similar to Clovis overface flaking (Figure 5b); however, this is rarely present on finished Cumberland bifaces. Once the general shape is obtained, one face is selected for fluting. Typically, each face was prepared and fluted individually. This likely represents a risk management strategy to minimize time and energy in case the first fluting attempt catastrophically broke the preform (Flenniken 1978). This was also recognized by Jolly (1972), and is exemplified in the example illustrated by Boldurian and McKeel (2011:110, Figure 4). The practice of preparing and fluting one face at a time has also been documented in Folsom technology, and interpreted as a cost minimizing strategy (Flenniken 1978). Systematic collateral pressure flakes were removed to create a distinct midline ridge. The ridge serves to guide the removal of the channel flake and ensure that it travels the desired distance. Other researchers have noted the importance of the midline ridge and suggest that it is the most distinguishing feature of Cumberland preforms (Cambon and Hulse 1961; Jolly 1972). Immediately prior to fluting, the base is beveled and a prominent striking platform is created. Similar to Folsom (Sellet 2004), the distal ends of some Cumberland preforms are blunted suggesting the use of an anvil or brace during fluting. If the removal of the first flute is successful, then the second face is prepared for fluting following the same process. It should be noted that on approximately $20 \%$ of bifaces examined only one face is fluted. Once the channel flakes have been successfully removed, another episode of lateral pressure flaking is done to shape the final form (Figure 5c). During this final step the distinctive waisted shape is created through intensive lateral pressure flaking, that also reduces and standardizes the flute width.

Figure 5. Examples of Cumberland preforms and a finished biface. A, Smithsonian National Museum of Natural History, Tennessee; B, Pinson State Archaeological Park (TDOA), Tennessee; and C, Parris Collection, Hardin County, Tennessee.

The sample of preforms available for study is inherently fragmented because only broken preforms would have typically been discard prior to completion. The sample of 52 preforms analyzed consists of 41 basal fragments, 9 nearly complete specimens, 1 midsection, and 1 distal 
tip fragment. The most common reason for abandonment was catastrophic breaks caused by plunging channel flakes. Because the preforms were discarded at various points in the reduction sequence, most measurements exhibit a high rate of variation. However, certain morphological characteristics may be distinguishing features of Cumberland preforms (Table 6). The ratio of basal width-to-maximum width is $3: 4$ with a relatively low CV of $19 \%$.

Table 6. Morphological characteristics of Cumberland preforms.

*** 1.5-COLUMN FITTING ***

\subsection{Patterns in Cumberland Breakage and Rejuvenation}

Just over half (54\%) of all finished Cumberland bifaces analyzed are fractured in some way. The majority of these $(n=290,61 \%)$ are basal fragments, while distal tips, midsections, and miscellaneous fragments account for the remaining 39\%. On specimens where data were available, $25 \%$ of bifaces were missing at least one ear, excluding recently broken specimens, which may be related to shock damage during impact. Thirteen percent exhibit impact damage to the tip based on the presence of "reverse flute scars," burination to the distal lateral edge, or crushing. The majority (70\%) of Cumberland basal fragments were transversely broken. Heating accounts for almost $10 \%$ of the fractures.

Of the complete, finished Cumberland bifaces analyzed, 28\% exhibited some type of rejuvenation (Figure 6). This does not include bifaces reworked into other tool types. Of reworked specimens, $18 \%$ retained evidence of impact damage near the distal tip, suggesting that Cumberland bifaces were typically rejuvenated back into their original function (Figure 6b).

\section{*** 2-COLUMN FITTING ***}

Figure 6. Cumberland bifaces in various stages of rejuvenation. A, Smithsonian National Museum of Natural History, Alabama; B, Trinity site, Lewis County, Kentucky; C, Parris Collection, Hardin County, Tennessee.

\section{Cumberland Technological Organization and Behavioral Inferences}

\subsection{The Cumberland Technological System}

The two attributes most directly related to hafting are fluting and lateral grinding. Surprisingly, flute length $(\mathrm{CV}=45 \%)$ and the lateral grinding length $(\mathrm{CV}=45 \%)$ are two of the most variable attributes of Cumberland bifaces. Thus, the length of flutes and grinding initially do not appear be significant to function. However, if the technological ratios of flute length-tomaximum length and length of grinding-to-maximum length are considered, then these two attributes become more informative. The proportions of these measures are more standardized than the specific lengths of the individual attributes. Furthermore, the technological ratios of flute length-to-maximum length and lateral grinding length-to-maximum length remain constant even after rejuvenation. Morphological ratios such as maximum length-to-width change significantly as bifaces are reduced (Kuhn and Miller 2015). Thus, it appears that technological ratios are informative and may reflect aspects of hafting and artifact use-lives. Cumberland bifaces have a relatively small width-to-thickness ratio compared to other late Pleistocene fluted bifaces (see Bever and Meltzer 2007; Smallwood 2012), resulting in a more robust morphology. 
The majority (80\%) of complete Cumberland bifaces are over $55 \mathrm{~mm}$ long, while the majority (82\%) of Cumberland basal fragments are less than $60 \mathrm{~mm}$ long. As such, it appears that the minimum threshold related to discard is approximately $55-60 \mathrm{~mm}$. Bifaces above that range are expected to be resharpened, if possible, while below that length they are expected to be discarded (Figure 7). Catastrophic transverse fractures typically occur below $55 \mathrm{~mm}$. Based on technological ratios and assuming that lateral grinding reflects hafting, there is only a slight correlation between hafting and maximum length $\left(r=0.54, r^{2}=0.30\right)$, suggesting that longer bifaces did not necessarily have longer hafts. Using the ratio of grinding length-to-maximum length, functional blade length can be inferred. The typical Cumberland biface was hafted $35 \%$ of its total length, with the remaining $65 \%$ serving as the functional blade. If the threshold for complete Cumberland biface length is $55-60 \mathrm{~mm}$, then the minimum functional blade length is calculated to $37.75-39.00 \mathrm{~mm}$. Once this threshold was reached, either because of breakage or exhaustion, the biface was likely replaced.

\section{*** 2-COLUMN FITTING ***}

Figure 7. Frequencies in the lengths of complete Cumberland bifaces and basal fragments.

\subsection{Biface Morphology}

Based on CVs for maximum dimensions and morphological ratios, the most standardized attributes of Cumberland bifaces are related to the basal element. This is not unexpected given that the haft element is subject to morphological constraints imposed by specific hafting techniques (Judge 1970; Keeley 1982; Roosa 1977). While lateral and distal resharpening of the blade element changes the overall morphology, the hafted basal element is less frequently modified (Bever and Meltzer 2007; Meltzer and Bever 1995).

In spite of overall basal morphology being generally standardized, basal concavity is highly variable. This pattern of variability in basal concavity may be related to several factors including being tailored to individual foreshafts, stylistic elements of haft construction, and rebasing of broken bifaces (Ellis 2004; Smallwood 2012; Taylor-Montoya 2007; White 2013). Daniel and Goodyear (2006; Goodyear 2006) suggest that increased basal concavity is related to a technological shift marking the cultural transition from the early to middle Paleoindian periods. While this pattern may hold true in the Clovis-to-Redstone transition in the Coastal Plain, it does not appear to be the case with Clovis-to-Cumberland in the Midsouth. Based on Smallwood's (2012) comprehensive study of regional Clovis morphology, Cumberland bifaces have slightly less basal concavity than Clovis bifaces.

\subsection{Breakage Patterns and Rejuvenation}

Cumberland bifaces appear to have been primarily resharpened from the distal tip. Distal resharpening is reflected in the standardization of face-angle and width dimensions, and the variability in length dimensions. Similar patterns of rejuvenation have also been noted on other post-Clovis fluted biface types such as Barnes and Folsom (e.g., Ahler and Geib 2000; Deller and Ellis 1992; Ellis 2004; Judge 1973). While biface morphology may be influenced by factors related to raw material, this does not appear to be the case in the Midsouth. The ubiquity of toolstone throughout much of the Midsouth (Amick 1987; Parish 2011, 2013), reduces 
potentially limiting factors caused by availability, quality, or general package size of local toolstone (Kuhn 1995).

Patterns of rejuvenation documented in Cumberland bifaces indicate that they were designed to be maintainable tools. The relatively constant widths of the bifaces, as well as the flutes, indicate that minimal resharpening occurred along the lateral margins after the biface was completed. The standardization of basal elements suggests that rejuvenating broken or dulled bifaces typically occurred with the biface in the haft. This suggests that Cumberland bifaces were not multifunctional tools, but rather were designed almost exclusively for piercing, as may be the case for other post-Clovis fluted biface types.

\subsection{The Organization of Technology and Settlement Organization}

The ubiquity of toolstone in the Midsouth neutralizes potential effects of resource availability, so that patterns in biface technologies more likely reflect organization strategies rather than differential access to raw materials (Kuhn 1995). The patterns evident in overall biface morphology, hafting, breakage, rejuvenation, and discard, reflect a logistically mobile settlement strategy based around the provisioning of places. As such, Cumberland bifaces were likely specialized piercing tools used by task groups on hunting forays. Similar to Folsom, Cumberland groups likely made and maintained bifaces as part of a gearing-up strategy during periods of downtime (Sellet 2004, 2013). The low ratio of complete to broken Cumberland bifaces indicates that transverse breaks were catastrophic. Although, making minor repairs to impact damaged bifaces could extend use-life. It is likely, however, that this is only part of a larger, more complex, landuse strategy that incorporated flexible provisioning strategies related to seasonal resource structure and demographic fluctuations associated with aggregation events.

\section{Conclusion}

Cumberland biface technology is prevalent throughout the Midsouth, specifically the Highland Rim of southern Kentucky, central Tennessee, and northern Alabama. Unlike other late Pleistocene technologies, Cumberland bifaces have never been recovered from intact, single component contexts associated with datable materials. The co-occurrence of Cumberland and other Paleoindian biface types in the same layer at sites such as Dust Cave is enigmatic. Additional sites with intact stratigraphy must be excavated to understand the intricacies of Paleoindian chronology in the Midsouth United States. Currently, there is a lack of tools and debitage, subsistence data, and radiometrically supported chronologies associated with Cumberland technology.

While Cumberland data is primarily limited to bifaces lacking context, analyses of over 900 bifaces indicate that Cumberland technology was designed as part of a logistical settlement strategy used by people mapping on to specific places on the landscape. The ubiquity of lithic raw materials and largely predictable distributions of resources allowed people using Cumberland technology to logistically map onto the woodland landscape of the Midsouth. Based on bracketing radiocarbon ages and technological similarities to other, well-dated biface technologies, Cumberland appears to be a post-Clovis manifestation contemporary to the earliest part of the YD (ca. 12,800-12,100 cal yr BP). However, more research is needed to further support this assertion. The hypotheses presented here should be further tested with additional 
technological studies of Cumberland sites with preservation of more complete toolkits and debitage.

\section{Acknowledgements}

Thanks to Michael Waters, Ted Goebel, and Kelly Graf for their guidance throughout this research and writing process. This research would not have been possible without the assistance of Suzanne Hoyle, John Broster, Mike Moore, Aaron Deter-Wolf, and Bill Lawrence of the Tennessee Division of Archaeology. I would like to extend special thanks to Phil Stratton of Kentucky; Jim and Ruth Parris of Tennessee; Elmer Guerri of Indian; Howard King of Alabama; Rex Moore and the entire staff of the Tennessee State Museum; Jim Walden of the Indian Mound and Museum in Florence, Alabama; and Dennis Stanford and Pegi Jodry of the Smithsonian Institute for allowing me to study their sites and collections. I would also like to thank Shane Miller, Heather Smith, Josh Lynch, and Tim de Smet for helping me work through the twists and turns of this project. Finally, I want to thank two anonymous reviewers whose comments and suggestions significantly improved the final product. 


\section{References}

Aagesen, Sonja

2006 The Determination of Paleo-Indian Territoriality Through the Exploratory Spatial Data Analysis of PaleoIndian Fluted Points and Their Lithic Sources. Masters thesis, Simon Fraser University.

Ahler, Stanely A. and Phil R. Geib 2000 Why Flute? Folsom Point Design and Adaptation. Journal of Archaeological Science 27:799-820.

Ahr, Steven W., Lee C. Nordt, and Steven L. Foreman 2013 Soil Genesis, Optical Dating, and Geoarchaeological Evaluation of Two Upland Alfisol Pedons within the Tertiary Gulf Coastal Plain. Geoderma 192:211-226.

Amick, Daniel S. (editor)

1999 Folsom Lithic Technology: Explorations in Structure and Variation. International Monographs in Prehistory, Archaeology Series, Volume 12. Anna Arbor.

Amick, Daniel S.

1987 Lithic Raw Mateiral Variability in the Central Duck River Basin: Reflections of Middle and Late Archaic Organizational Strategies. TVA Publications in Anthropology No. 50, Report of Investigations No. 46, Department of Anthropology, University of Tennessee, Knoxville.

1995 Patterns of Technological Variation Among Folsom and Midland Projectile Points in the American Southwest. Plains Anthropologist 40(151):23-38.

Anderson, David G.

1990 Paleoindian Colonization of Eastern North America: A View from the Southeast. In Early Paleoindian Economies of Eastern North America, edited by Kenneth Tankersley and Barry Isaac, pp. 163-216. Research in Economic Anthropology Supplement 5.

1996 Models of Paleoindian and Early Archaic Settlement in the Lower Southeast. In The Paleoindian and Early Archaic Southeast, edited by D. G. Anderson and K. E. Sassaman, pp. 29-57. University of Alabama Press, Tuscaloosa.

2004 Paleoindian Occupations in the Southeastern United States. In New Perspectives on the First Americans, edited by Bradley T. Lepper and Robson Bonnichsen, pp. 119128. Texas University Press, College Station.

Anderson, David G. and J. Gillam 2000 Paleoindian Colonization of the Americas: Implications form an Examination of Physiography, Demography, and Artifact Distribution. American Antiquity 65:43-66. 
Anderson, David G. and Kenneth E. Sassaman (editors)

1996 The Paleoindian and Early Archaic Southeast. University of Alabama Press, Tuscaloosa.

2012 Recent Developments in Southeastern Archaeology. Society for American Archaeology Press, Washington D.C.

Anderson, David G., Ashley Smallwood, and D. Shane Miller

2015 Pleistocene Human Settlement in the Southeastern United States: Current

Evidence and Future Directions. PaleoAmerica 1(1):7-51.

Anderson, David G., D. Shane Miller, Stephen J. Yerka, J. Christopher Gillam, Erik N.

Johanson, Derek T. Anderson, Albert C. Goodyear, and Ashley M. Smallwood

2010 PIDBA (Paleoindian Database of the Americas) 2010: Current Status and

Findings. Archaeology of Eastern North America 38:63-90.

Anderson, David G., Albert C. Goodyear, James Kennett, and Allen West

2011 Multiple Lines of Evidence for Possible Human Population Decline/Settlement

Reorganization During the Early Younger Dryas. Quaternary International 242:570-583.

Andrefsky, William Jr.

2010 Human Land Use Strategies and Projectile Point Damage, Resharpening and

Discard Patterns. Human Evolution 25 (1-2):13-30.

Bateman, M.D., Boulter, C.H., Carr, A.S., Frederick, C.D., Peter, D., and Wilder, M. 2007a Preserving the Palaeoenvironmental Record in Drylands: Bioturbation and its Significance for Luminescence Derived Chronologies. Sedimentary Geology 195:5-19.

2007b Detecting Post-Depositional Sediment Disturbance in Sandy Deposits Using Optical Luminescence. Quaternary Geochronology 2:57-64.

Barker, Gary and John B. Broster

1996 The Johnson Site (40DV400): A Dated Paleoindian and Early Archaic Occupation in Tennessee's Central Basin. Journal of Alabama Archaeology 42(2):97-153.

Bell, Robert E.

1960 Cumberland Points. In Guide to the Identification of Certain American Indian

Projectile Points. Oklahoma Anthropological Society, Special Bulletin No. 2, pp. 22-23.

Bettis, Arthur E. III, Daniel R. Muhs, Helen M. Roberts, and Ann G Wintle 2003 Last Glacial Loess in the Conterminous USA. Quaternary Science Reviews 22:1907-1946.

Bever, Michael R. and David J. Meltzer 2007 Exploring Variation in Paleoindian Life Ways: The Third Revised Edition of the Texas Clovis Fluted Point Survey. Bulletin of the Texas Archaeological Society 78:65-99. 
Binford, Lewis, R.

1979 Organization and Formation Processes: Looking at Curated Technologies. Journal of Anthropological Research 35(3):255-273.

1980 Willow Smoke and Dogs' Tails: Hunter-Gatherer Settlement Systems and Archaeological Site Formation. American Antiquity 45(1):4-20.

Boldurian, Anthony T. and Justin D. McKeel

2011 A Cumberland Preform: Implications for Paleoindian Lithic Technology. North American Archaeologist 32(2):97-129.

Bradley, Bruce A., Michael B. Collins, and Andrew Hemmings 2010 Clovis Technology. International Monographs in Prehistory, Archaeological Series 17, Ann Arbor.

Bradley, James W., Arthur E. Spiess, Richard A. Boisvert, and Jeff Boudreau 2008 What's the Point? Modal Forms and Attributes of Paleoindian Bifaces in the New England-Maritimes Region Archaeology of Eastern North America. 36:119-172.

Breitburg, Emanuel and John B. Broster 1994 Paleoindian Site, Lithic, and Mastodon Distributions in Tennessee. Current Research in the Pleistocene 11:9-11.

Brose, D. S.

1994 Archaeological investigations at the PaleoCrossing site, a Paleoindian occupation in Medina County, Ohio. In The First Discovery of America: Archaeological Evidence of the Early Inhabitants of the Ohio Area, edited by W. Dancey, 61-76. Columbus: Ohio Archaeological Council.

Broster, John B. and Mark R. Norton 1996 Recent Paleoindian Research in Tennessee. In The Paleoindian and Early Archaic Southeast, edited by D. G. Anderson and K. E. Sassaman, pp. 288-297. University of Alabama Press, Tuscaloosa.

Broster, John B., Mark R. Norton, D. Shane Miller, Jesse W. Tune, and John D. Baker 2013 Tennessee's Paleoindian Record: The Cumberland and Lower Tennessee River Watersheds. In In The Eastern Fluted Point Tradition, edited by Joseph A.M. Gingerich, 299-314. University of Utah Press, Salt Lake City.

Cambron, James W. and David C. Hulse 1961 A Comparative Study of Some Unfinished Fluted Points and Channel Flakes from the Tennessee Valley. Journal of Alabama Archaeology 7(2):88-105.

Collins, Michael B. 
1990 Observations on Clovis Lithic Technology. Current Research in the Pleistocene 7:73-74.

Daniel, Randle I. Jr., and Albert C. Goodyear 2006 An Update on the North Carolina Fluted-Point Survey. Current Research in the Pleistocene 23:88-90.

Deller, Brian D. and Christopher J. Ellis

1992 Thedford II: A Paleo-Indian Site in the Ausable River Watershed of Southwestern Ontario. Memoirs, Museum of Anthropology, University of Michigan, No. 24, Ann Arbor.

Driskell, Boyce N.

1994 Stratigraphy and Chronology at Dust Cave. Journal of Alabama Archaeology 40(1-2):17-34.

19961996 Stratified Late Pleistocene and Early Holocene Deposits at Dust Cave, Northeastern Alabama. In The Paleoindian and Early Archaic Southeast, edited by David G. Anderson and Kenneth E. Sassaman, pp. 315-330. University of Alabama Press, Tuscaloosa.

Driskell, Boyce N., Scott C. Meeks, and Sarah C. Sherwood 2012 The Transition from Paleoindian to Archaic in the Middle Tennessee Valley. In From the Pleistocene to the Holocene: Human Organization and Cultural Transformations in Prehistoric North America, edited by C. Britt Bousman and Bradley J. Vierra, pp. 253-271. Texas A\&M University Press, College Station.

Eerkens, Jelmer W. and Robert L. Bettinger 2001 Techniques for Assessing Standardization in Artifact Assemblages: Can We Scale Material Variability? American Antiquity 66(3):493-504.

Ellis, Christopher

2004 Understanding "Clovis" Fluted Point Variability in the Northeast: A Perspective from the Derbert Site, Nova Scotia. Canadian Journal of Archaeology 28:205-253.

Ellis, Christopher J. and D. Brian Deller 1997 Variability in the Archaeological Record of Northeastern Paleo-Indians: A View from Southern Ontario. Archaeology of Eastern North America 25:1-30.

Eren, Metin I., Stanley Vanderlaan, and John D. Holland 2011 Overshot Flaking at the Arc Site, Genesee County, New York: Examining the Clovis-Gainey Connection. The Open Anthropology Journal 4:40-52.

Fiedel, Stuart J. 1999 Older Than We Thought: Implications of Corrected Dates for Paleoindians. American Antiquity 64(1):95-115. 
Flenniken, Jeffery J.

1978 Reevaluation of the Lindenmeier Folsom: A Replication Experiment in Lithic Technology. American Antiquity 43(3):473-480.

Futato, Eugene M.

1996 A Synopsis of Paleoamerican and Early Archaic Research in Alabama. In The Paleoamerican and Early Archaic Southeast, edited by David G. Anderson and Kenneth Sassaman, pp. 331-353. University of Alabama Press, Tuscaloosa.

Frison and Stanford

1982 The Agate Basin Site: A Record of the Paleoindian Occupation of the Northwestern High Plains. Academic Press, New York.

Gingerich, Joseph A. M. (editor)

2013 In the Eastern Fluted Point Tradition. University of Utah Press, Salt Lake City.

Goodyear, Albert C.

1999 The Early Holocene Occupation of the Southeastern United States: A Geoarchaeological Summary. In Ice Age Peoples of North America: Environments, Origins, and Adaptations, edited by R. Bonnichsen and K. L. Turnmire, pp. 432-481. Oregon State University Press, Corvallis.

2006 Recognizing the Redstone Fluted Point in the South Carolina Paleoindian Point Database. Current Research in the Pleistocene 23:100-103.

2010 Instrument-Assisted Fluting as a Technochronological Marker Among North American Paleoindian Points. Current Research in the Pleistocene 27:86-88.

2013 Update on the 2012-2013 Activities of the Southeastern Paleoamerican Survey. Legacy 17(1):10-12. Newsletter of the South Carolina Institute of Archaeology and Anthropology. Columbia: University of South Carolina.

Gramly, Richard M.

2008 The Cumberland/Barnes Tradition: Its Character and Chronological Position within a Greater Fluted Point Tradition. Ohio Archaeologist 58(2):4-15.

2009 Origin and Evolution of the Cumberland Palaeo-American Tradition. Special Publication of the American Society for Amateur Archaeology, Partner's Press, Kenmore.

2012 Bifaces of the Cumberland Tradition. Special Publication of the American Society for Amateur Archaeology, Partner's Press, Kenmore.

2013 Utilized Prismatic Blades vs. Utilized Flakes at the Phil Stratton Cumberland Site, Kentucky. North American Archaeologist 34(2):137-167. 
2015 A Review of the Cumberland Fluted Point Tradition in Relation to the Dutchess Quarry Caves (NY) and the Phil Stratton Site (KY). American Society for Amateur Archaeology, online journal.

Hill, Mathew E. Jr.

2001 Paleoindian Diet and Subsistence Behavior on the Northwestern Great Plains of North America, Unpublished Dissertation, Department of Anthropology, University of Wisconsin-Madison, Madison.

Hill, Mathew E. Jr. and Jack L. Hofman

1997 The Waugh Site: A Folsom-Age Bison Bonebed in Northwestern Oklahoma. In Southern Plains Bison Procurement and Utilization From Paleoindian to Historic, edited by Leland Bement and Kent J. Buehler, pp. 63-83. Plains Anthropologist Memoir 29. Lincoln.

Hofman, Jack L. 1995 Dating Folsom Occupations on the Southern Plains: Lipscomb and Waugh Sites. Journal of Field Archaeology 13:341-370.

1992 Recognition and Interpretation of Folsom Technological Variability on the Southern Plains. In Ice Age Hunters of the Rockies, edited by Dennis J. Stanford and Jane S. Day, pp. 193-224. University Press of Colorado, Boulder.

Hollenbach, Kandace D. and Renee B. Walker

2010 Documenting Subsistence Change During the Pleistocene/Holocene Transition: Investigations of Paleoethnobotanical and Zooarchaeological Data from Dust Cave, Alabama. In Integrating Zooarchaeology and Paleoethnobotany: A Consideration of Issues, Methods, and Cases, edited by A.M. VanDerwarker and T.M. Peres, pp. 227-244. Springer Press, Dordrecht.

Jennings, Thomas A.

2012 Clovis, Folsom, and Midland Components at the Debra L. Friedkin Site, Texas: Context, Chronology, and Assemblages. Journal of Archaeological Science 39:32393247.

2013 The Hogeye Clovis Cache, Texas: Quantifying Lithic Reduction Signatures. Journal of Archaeological Science 40(1):649-658.

Johnson, William C. and Karen L. Willey 2000 Isotopic and Magnetic Expression of Environmental Change at the PleistoceneHolocene Transition in the Central Great Plains. Quaternary International 67:89-106.

Jolly, Fletcher, III

1972 Unfinished Fluted Points and Fluted Point Manufacture in the Tennessee Valley. Tennessee Archaeologist 28(2):60-97. 
Judge, James W.

1970 Systems Analysis and the Folsom-Midland Question. Southwestern Journal of Anthropology 26(1):40-51.

1973 Paleoindian Occupation of the Central Rio Grande Valley in New Mexico. University of New Mexico Press, Albuquerque.

Justice, Noel D.

1987 Stone Age Spear and Arrow Points of the Midcontinental and eastern United States. Indiana University Press, Bloomington.

Keeley, Lawrence H.

1982 Hafting and Retooling: Effects on the Archaeological Record. American Antiquity 47(4):798-809.

King, Howard

2007 Heaven's Half Acre: A Northwest Alabama Paleo-Indian Complex. Stones and Bones 49(4):1-9.

Kuhn, Steven L.

1990 A Geometric Index of Reduction for Unifacial Stone Tools. Journal of Archaeological Science 17:583-593.

1992 On Planning and Curated Technologies in the Middle Paleolithic. Journal of Anthropological Research 48(3):185-214.

1995 Mousterian Lithic Technology: An Ecological Perspective. Princeton University Press, Princeton.

Kuhn, Steven L., D. Shane Miller

2015 Artifacts as Patches: The Marginal Value Theorem and Stone Tool Life Histories. In Lithic Technological Systems and Evolutionary Theory, edited by Nathan Goodale and William Andrefsky, Jr., pp. 172-197. Cambridge University Press, Cambridge.

Lanata, J., L. Martino, A. Osella, and A. Garcia-Herbst 2008 Demographic Conditions Necessary to Colonize New Spaces: The Case for Early Human Dispersal in the Americas. World Archaeology 40:520-537.

Lewis, Thomas M. N.

1954 The Cumberland Point. Bulletin of the Oklahoma Anthropological Society II: 7-8.

May, David W. and Steven R. Holen

2003 Eolian and Soil Stratigraphy at a Paleoindian Site along the South Platte River Valley, Nebraska, U.S.A. Geoarchaeology: An International Journal 19(1):145-159.

McAvoy, Joseph M. and Lynn D. McAvoy 
1997 Archaeological Investigations of Site 44SX202, Cactus Hill, Sussex County, Virginia. Research Report Series No. 8. Richmond: Virginia. Department of Historic Resources.

Meeks, Scott and David G. Anderson

2012 Evaluating the Effect of the Younger Dryas on Human Population Histories in the Southeastern United States. In Hunter-Gatherer Behavior: Human Responses During the Younger Dryas, edited by Metin I. Eren, pp. 111-138. Left Coast Press, Walnut Creek.

Meltzer, David J.

2006 Folsom: New Archaeological Investigations of a Classic Paleoindian Bison Kill. University of California, Berkley.

2009 First Peoples in a New World: Colonizing Ice Age America. University of California Press, Berkley.

Meltzer, David J. and Michael R. Bever

1995 Paleoindians of Texas: An Update on the Texas Clovis Fluted Point Survey.

Bulletin of the Texas Archeological Society 66:17-51.

Miller, D. Shane

2011 Rivers, Rocks, and Eco-Tones: Modeling Clovis Landscape-Use in the Southeastern United States. Paper presented at the 76th Annual Meeting of the Society for American Archaeology, Sacramento.

Miller, D. Shane and Joseph A. M. Gingerich 2013 Regional Variation in the Terminal Pleistocene and Early Holocene Radiocarbon Record of Eastern North America. Quaternary Research 79:175-188.

Morrow, Juliet E. and Toby A. Morrow 1999 Variation in Fluted Projectile Points: A Hemispheric Perspective. American Antiquity 64(2):215-230.

Morse, Dan F., Phyllis A. Morse, and John Waggonee 1964 Fluted Points from Smith County, Tennessee. Tennessee Archaeologist 20(1):1634.

Muhs, D.R., J. N. Aleinikoff, T.W. Stafford Jr., R. Kihl, J. Been, S. A. Mahan, S. Cowherd, S. 1999 Late Quaternary Loess in Northeastern Colorado: Part I-Age and Paleoclimatic Significance. Geological Society of America Bulletin 111:1861-1875.

Muhs, D. R., E. Arthur Bettis III, Jossh Beann, John P. McGeehin 2001 Impact of Climate and Parent Material on Chemical Weathering in Loess-Derived Soils of the Mississippi River Valley. Soil Science Society of America Journal 65:17611777. 
Muhs, D. R., E. Arthur Bettis III, John N. Aleinikoff, John P. McGeehin, Jossh Beann 2008 Origin and Paleoclimatic Significance of Late Quaternary Loess in Nebraska: Evidence from Stratigraphy, Chronology, Sedimentology, and Geochemistry. Geological Society of America Bulletin 120:1378-1407.

Nelson, Margaret C.

1991 The Study of Technological Organization. In Archaeological Method and Theory, edited by Michael B. Schiffer, pp. 57-100. University of Arizona Press, Tucson.

O’Brien, Michael J., Matthew T. Boulanger, Briggs Buchanan, Mark Collard, R. Lee Lyman, John Darwent

2014 Innovation and Cultural Transmission in the American Paleolithic: Phylogenetic Analysis of Eastern Paleoindian Projectile-Point Classes. Journal of Anthropological Archaeology 34:100-119.

O’Brien , Michael J., John Darwent, and R. Lee Lyman 2001 Cladistics Is Useful for Reconstructing Archaeological Phylogenies: Palaeoindian Points from the Southeastern United States. Journal of Archaeological Science 28:11151136.

Parish, Ryan M.

2011 The Application of Visible/Near-Infrared Reflectance (VNIR) Spectroscopy to Chert: A Case Study from the Dover Quarry Sites, Tennessee. Geoarchaeology: An International Journal 26(3):420-439.

2013 Relationships Between Procurement Strategies and Geologic Provenience at the Dover Quarry Site Complex, Tennessee. North American Archaeologist 34(4):369-385.

Pitblado, Bonnie L.

2003 Late Paleoindian Occupation of the Southern Rocky Mountains. University Press of Colorado, Boulder.

Prasciunas, Mary M.

2011 Mapping Clovis: Projectile Points, Behavior, and Bias. American Antiquity 76(1):107-126.

Roosa, William B. and Christopher Ellis 2000 Fluted Bifaces and Other Bifacial Tools. In An Early Paleo-Indian Site near Parkhill, Ontario, edited by Christopher Ellis and D. Brian Deller, pp. 67-96. University of Washington Press,

Roosa, William B.

1977 Great Lakes Paleoindian: The Parkhill Site, Ontario. Annals of the New York Academy of Sciences 288:349-354.

Seeman, Make F. and Olaf H. Prufer 
1982 An Updated Distribution of Ohio Fluted Points. Midcontinental Journal of Archaeology 7(2):155-169.

Seeman, Make F., Garry Summers, Elaine Dowd, Larry Morris

1994 Fluted Point Characteristics at Three Large Sites: The Implications for Modeling

Early Paleoindian Settlement Patterns in Ohio, In The First Discovery of America:

Archaeological Evidence of the Early Inhabitants of the Ohio Area, edited by W. Dancey, pp. 77-93. The Ohio Archaeological Council, Columbus.

Sellet, Frederic

2004 Beyond the Point: Projectile Manufacture and Behavioral Inference. Journal of Archaeological Science 31:1553-1566.

2013 Anticipated Mobility and its Archaeological Signature: A Case Study of Folsom Retooling Strategies. Journal of Anthropological Archaeology 32:383-396.

Sherwood, Sarah C., Boyce N. Driskell, Asa R. Randall, Scott C. Meeks 2004 Chronology and Stratigraphy at Dust Cave, Alabama. American Antiquity 69(3):533-554.

Shott, Michael J.

1986 Technological Organization and Settlement Mobility: An Ethnographic Examination. Journal of Anthropological Research 42(1):15-51.

2013 Human Colonization and Late Pleistocene Lithic Industries of the Americas. Quaternary International 285:150-160.

Smallwood, Ashley M.

2012 Clovis Technology and Settlement in the American Southeast Using Biface Analysis to Evaluate Dispersal Models. American Antiquity, 77(4):689-713.

Smallwood, Ashley M., Thomas A. Jennings, David G. Anderson, and Jerald Ledbetter 2015 Testing for Evidence of Paleoindian Responses to Environmental Changes During the Younger Dryas Chronozone in Georgia. Southeastern Archaeology 34(1):23-45.

Tankersley, Kenneth B.

1989 Late Pleistocene Lithic Exploitation and Human Settlement in the Midwestern United States. Dissertation, Department of Anthropology, Indiana University, Bloomington.

1990 Late Pleistocene Lithic Exploitation in the Midwest and Midsouth: Indiana, Ohio, and Kentucky. In Early Paleoindian Economies of Eastern North America, edited by K. B. Tankersley and B. L. Isaac, pp. 259-299. Research in Economic Anthropology Supplement 5. JAI Press, Greenwich, Connecticut.

1994 The Effects of Stone and Technology on Fluted-Point Morphometry. American Antiquity 59(3):498-510. 
1996 Ice Age Hunters and Gatherers. In The Prehistory of Kentucky, edited by R. B. Lewis. University of Kentucky Press, Lexington.

Taylor-Montoya, John J.

2007 Quantitative Variation in Late Paleoindian Projectile Points: A Perspective from Central Texas. Bulletin of the Texas Archeological Society 78:161-176.

Thulman, David K. 2006 A Reconstruction of Paleoindian Social Organization in North Central Florida. Ph.D. Dissertation, Department of Anthropology, Florida State University, Tallahassee.

Torrence, Robin

1983 Time Budgeting and Hunter-Gatherer Technology. In Hunter-Gatherer Economy in Prehistory : A European Perspective, edited by G. Bailey, pp. 11-22. Cambridge University Press, Cambridge.

Tune, Jesse W.

2016 The Clovis-Cumberland-Dalton Succession: Settling into the Midsouth United States During the Pleistocene-to-Holocene Transition. PaleoAmerica (in press).

Tune, Jesse W., Judith A. Melton

2013 Interpreting Activity Areas and Cumberland Lithic Technology at the Phil Stratton Site, Kentucky. Poster presented at the Paleoamerican Odyssey Conference, Santa Fe, New Mexico.

Tune, Jesse W., Adam Finn, Ryan Parish, Aaron Deter-Wolf, and Nathan Allison 2015 The Parris Collection: A Life-Long Dedication to Archaeology. Poster presented at the 27th annual meeting of Current Research in Tennessee Archaeology, Nashville, Tennessee.

Waters, Michael R., Thomas W. Stafford Jr., Brian G. Redmond, Kenneth B. Tankersley 2009 The Age of the Paleoindian Assemblage at Sheriden Cave, Ohio. American Antiquity 74(1):107-111.

Waters, Michael R., Charlotte D. Pevny, and David L. Carlson 2011 Clovis Lithic Technology: Investigation of a Stratified Workshop at the Gault Site, Texas. Texas A\&M University Press, College Station.

Waters, Michael R. and Thomas A. Jennings 2015 The Hogeye Cache. Center for the Study of the First Americans, Texas A\&M University Press, College Station.

White, Andrew A. 2006 A Model of Paleoindian Hafted Biface Chronology in Northeastern Indiana. Archaeology of Eastern North America 43:29-59. 
2013 Functional and Stylistic Variability in Paleoindian and Early Archaic Projectile Points from Midcontinental North America. North American Archaeologist 34:71-108. 
Table 1. Collections included in analyses.

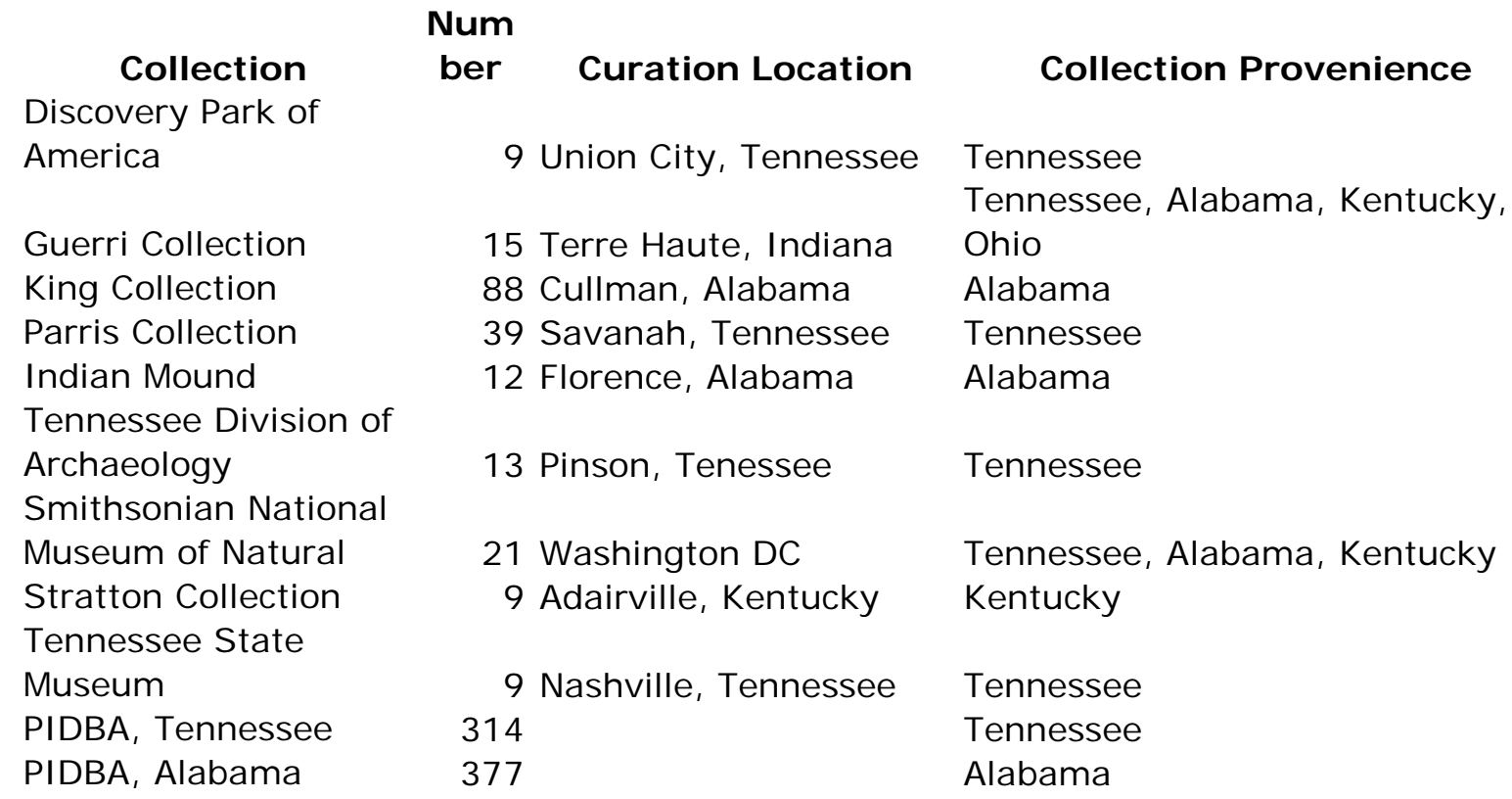


Table 2. Cumberland bifaces included in analyses.

\begin{tabular}{|c|c|c|c|c|}
\hline \multirow[b]{2}{*}{ Condition } & \multirow[b]{2}{*}{ Collections } & \multicolumn{2}{|c|}{ PIDBA } & \multirow[b]{2}{*}{ Total } \\
\hline & & Tennessee & Alabama & \\
\hline Complete & 85 & 206 & 104 & 395 \\
\hline Base & 76 & 59 & 155 & 290 \\
\hline Midsection/Dista & 27 & 28 & 108 & 163 \\
\hline Fragments & 0 & 16 & 6 & 22 \\
\hline Preforms & 28 & 5 & 4 & 37 \\
\hline Total & 216 & 314 & 377 & 907 \\
\hline
\end{tabular}


Table 3. Expected characteristics of provisioning strategies.

Mobility

Provisioning Provisionin

Intensity of use

Rejuvenation

Reason for discard

Complete: Broken

Individuals

g Place

Residentially Logistically

Intensive Non-intensive

High Low

Exhausted Broken

High Low 
Table 4. Morphological characteristics of Cumberland bifaces.

Maximum Width

Basal Width

Maximum Length

Waist Width

Waist Width: Basal Width

Waist Width: Maximum Width

Length: Width

Depth of Basal Concavity

Depth of Basal Concavity: Basal Wid

Maximum Thickness

Width:Thickness

Lateral Indentation Index

Inter Flute Thickness

Face-angle

\begin{tabular}{rrrr|}
\multicolumn{1}{c}{ Average } & Maximum & Minimum & CV \\
\hline 23.83 & 52.17 & 10.00 & 0.17 \\
20.95 & 35.61 & 10.00 & 0.18 \\
75.07 & 167.88 & 24.91 & 0.33 \\
20.78 & 40.50 & 13.97 & 0.22 \\
0.85 & 1.23 & 0.00 & 0.24 \\
0.74 & 1.14 & 0.00 & 0.31 \\
3.14 & 6.02 & 1.12 & 0.26 \\
3.17 & 11.02 & 0.00 & 0.51 \\
0.15 & 1.33 & 0.00 & 0.67 \\
7.58 & 19.00 & 2.82 & 0.21 \\
3.23 & 7.40 & 1.16 & 0.22 \\
0.07 & 0.10 & 0.02 & 0.26 \\
5.43 & 8.16 & 3.45 & 0.18 \\
92.60 & 101.35 & 82.05 & 0.04
\end{tabular}


Table 5. Technological characteristics of Cumberland bifaces.

Average Grind Length

Average Grind Length: Maximum Length Average Flute Length

Average Flute Length: Maximum Length

Average Flute Width

\begin{tabular}{rrrr|} 
Average & Maximum & Minimum $C V$ & \\
\hline 25.47 & 69.85 & 0.00 & 0.44 \\
0.35 & 0.80 & 0.00 & 0.39 \\
46.32 & 118.61 & 7.00 & 0.45 \\
0.60 & 1.00 & 0.00 & 0.41 \\
11.49 & 27.58 & 4.00 & 0.29
\end{tabular}


Table 6. Morphological characteristics of Cumberland preforms.

Maximum Width

Basal Width

Waist Width

Maximum Thickness

Waist Width: Basal Width

Depth of Basal Concavity

Depth of Basal Concavity: Basal Wid

Inter Flute Thickness

Average Flute Width

Average Maximum

35.15

25.85

28.10

8.14

0.83

2.71

0.09

5.09

17.92

57.29

35.61

37.60

11.14

0.99

6.47

0.18

6.91

28.82
Minimum CV

26.29

17.59

0.21

20.28

0.18

0.22

4.89

0.18

0.64

0.13

0.60

0.73

0.03

0.61

3.79

0.21

11.97

0.26 


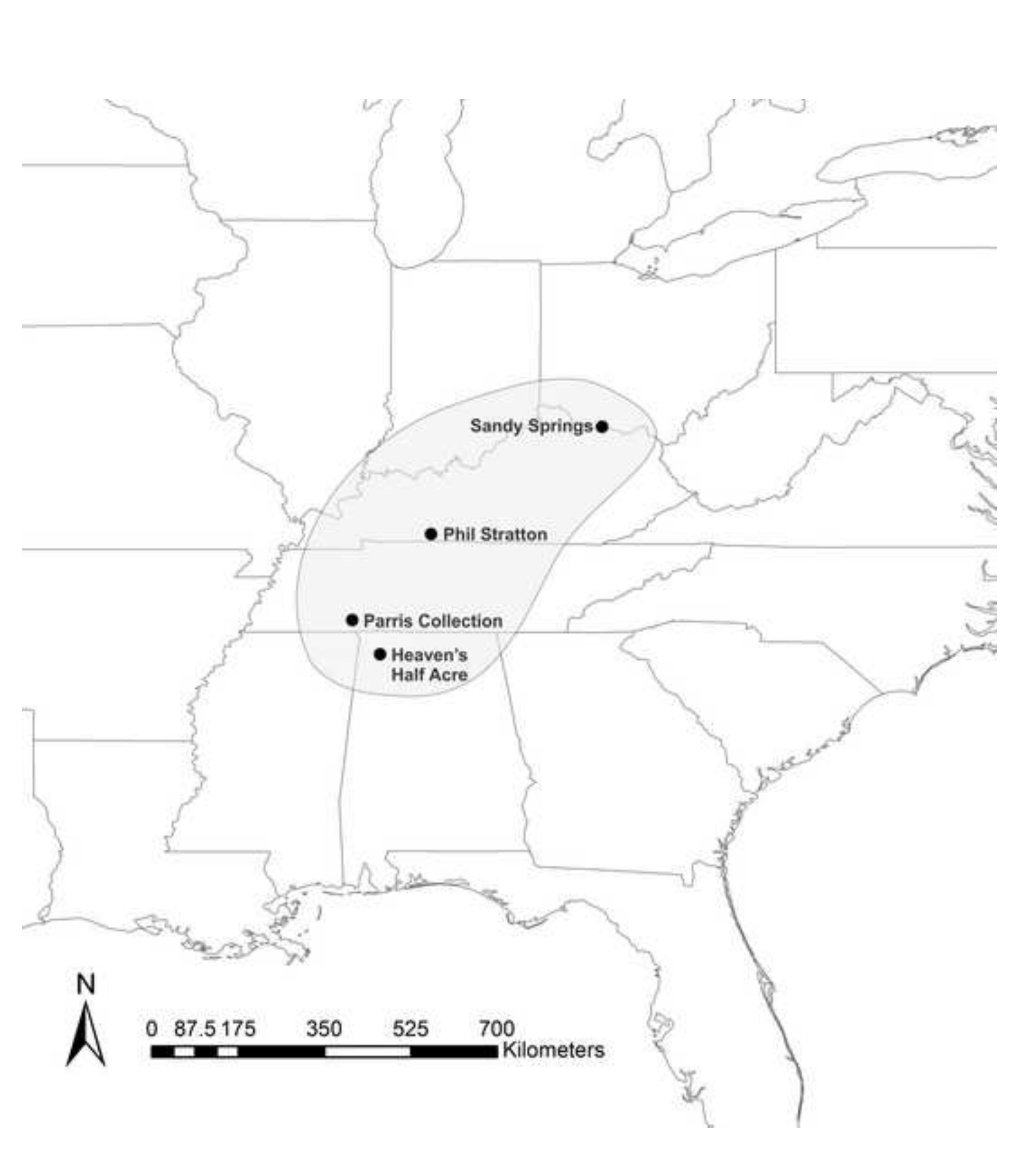

.
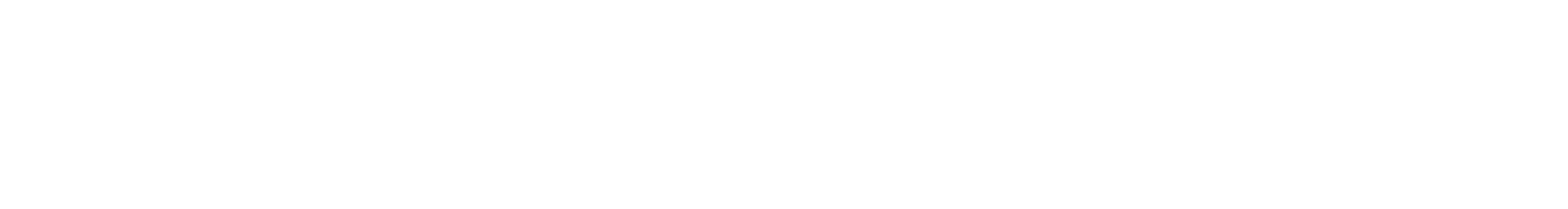

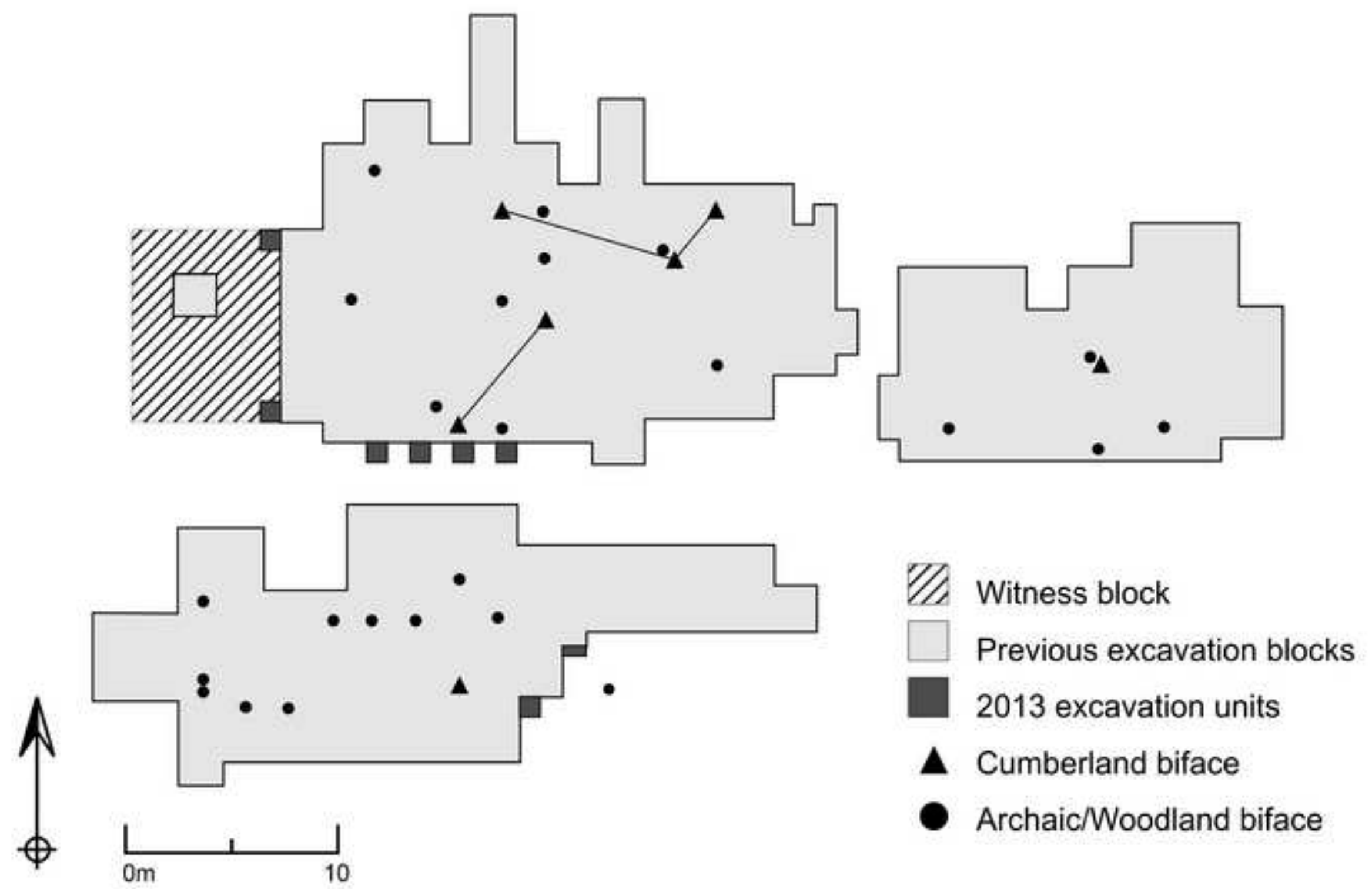

Wh Witness block

$\square$ Previous excavation blocks

2013 excavation units

A Cumberland biface

- Archaic/Woodland biface 


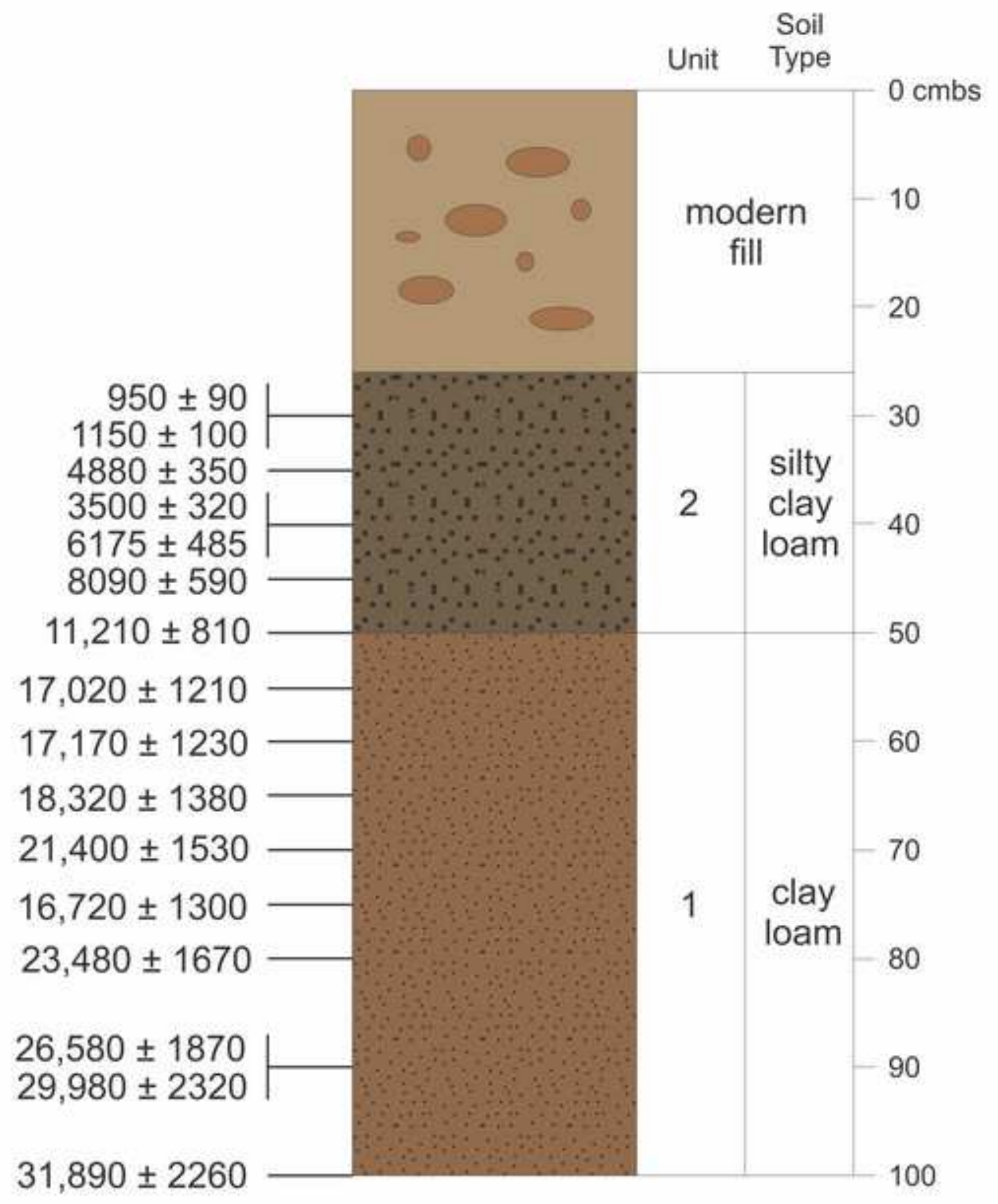




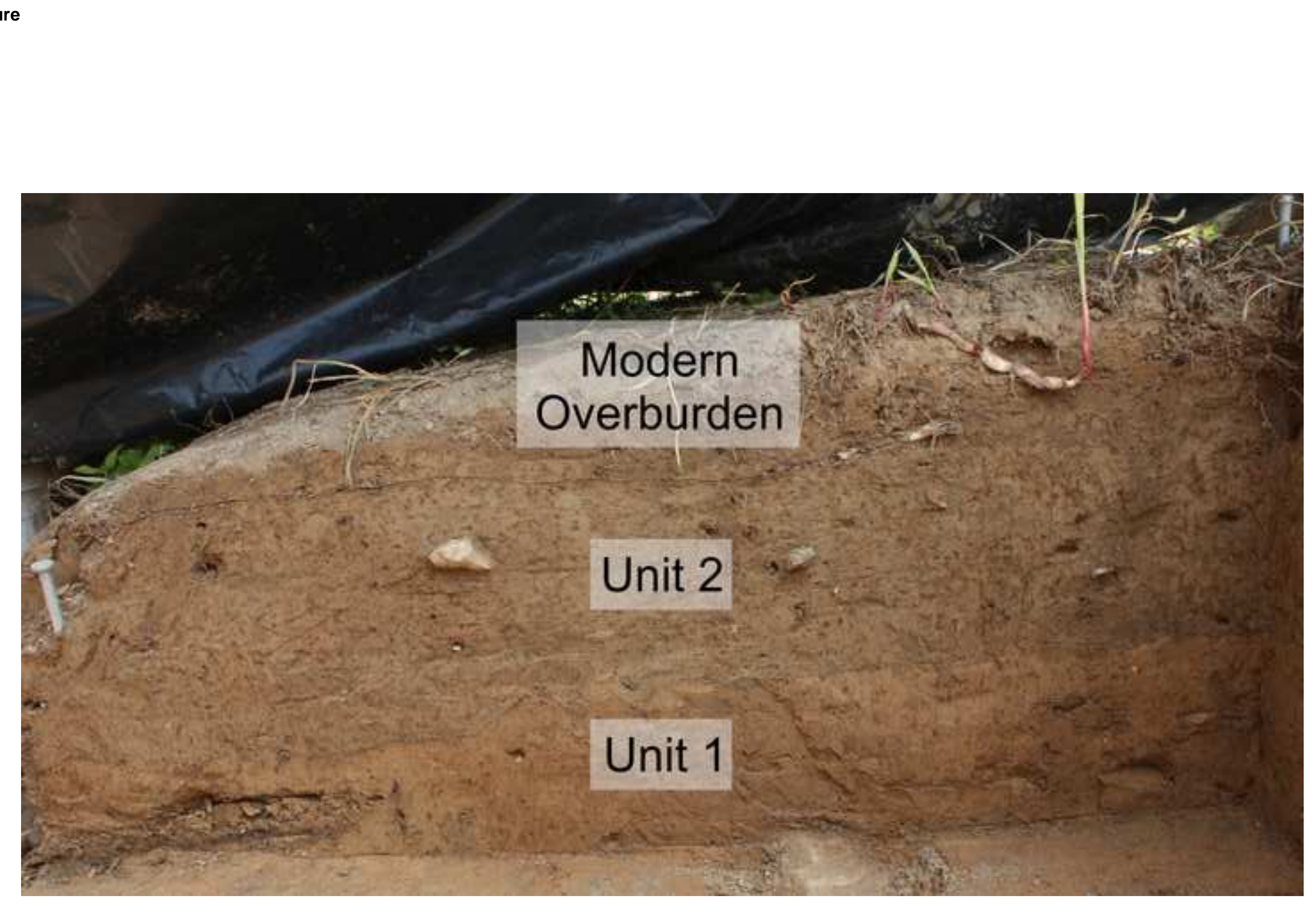

\section{Modern Overburden}
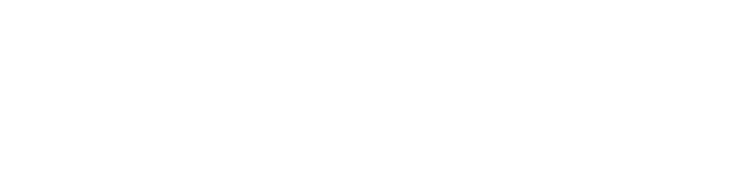

\author{
Unit 2
}

Unit 1
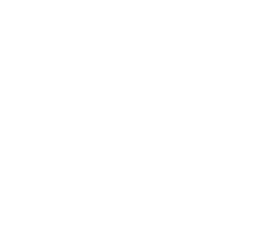


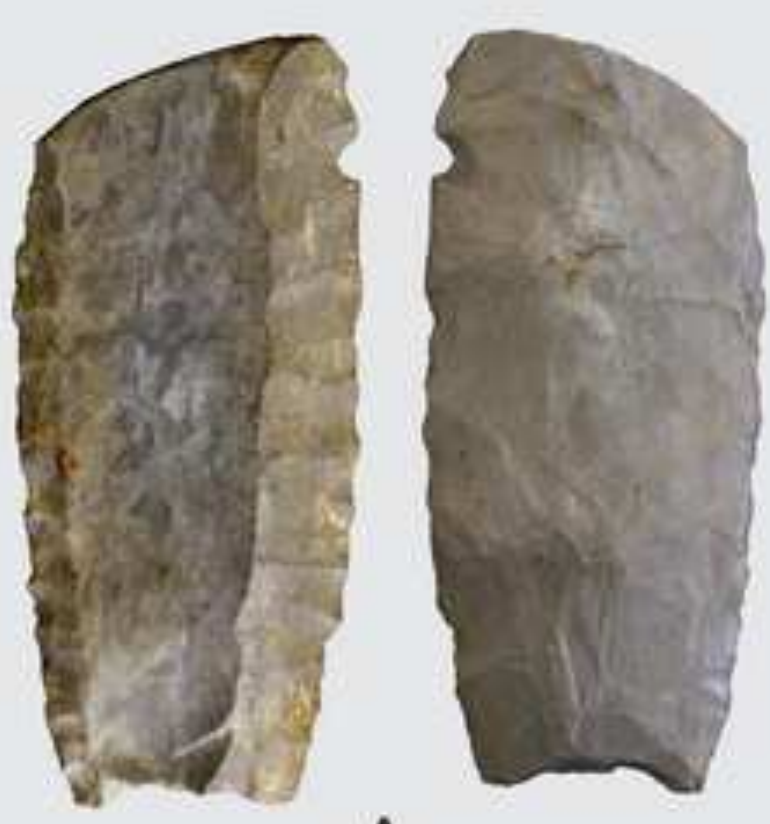

A
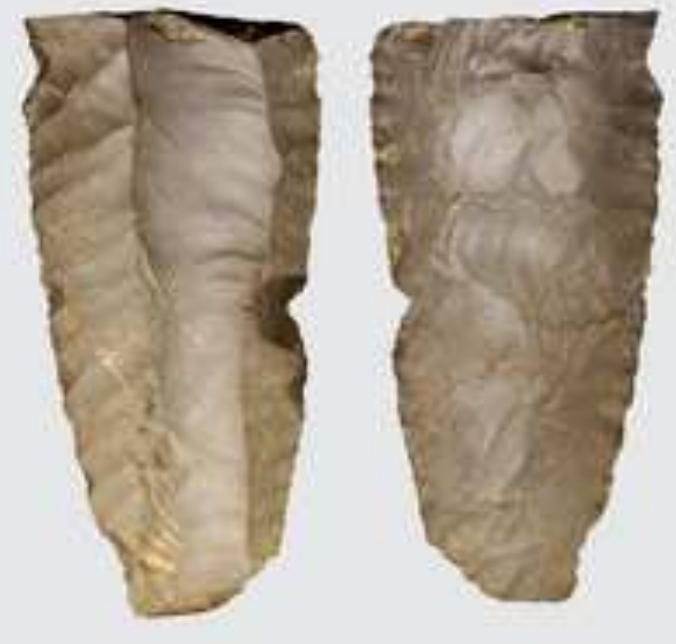

B
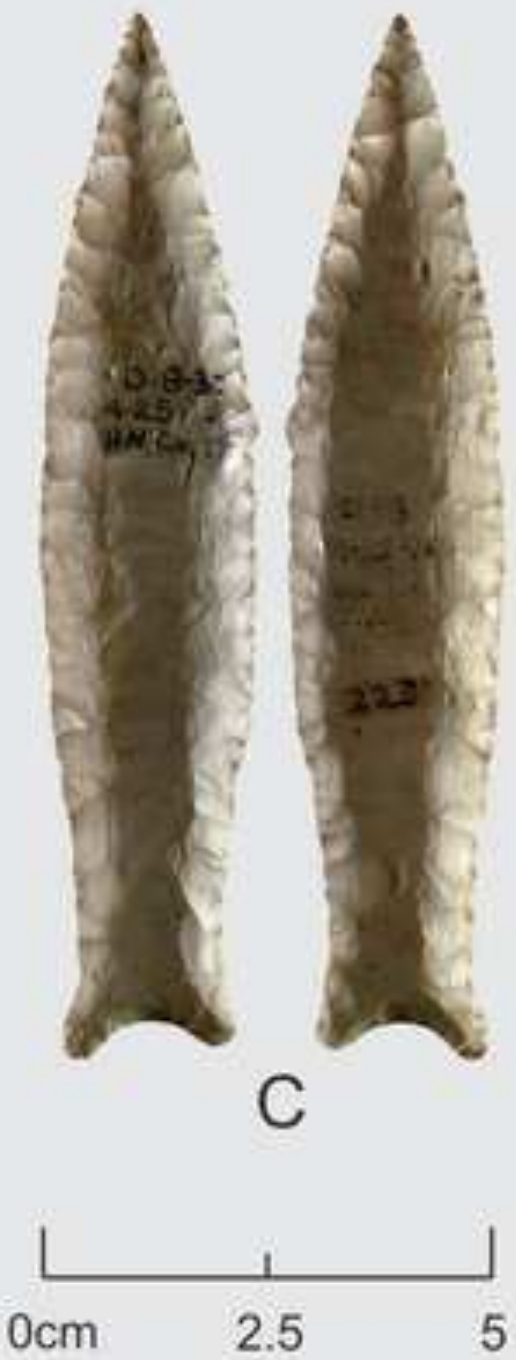


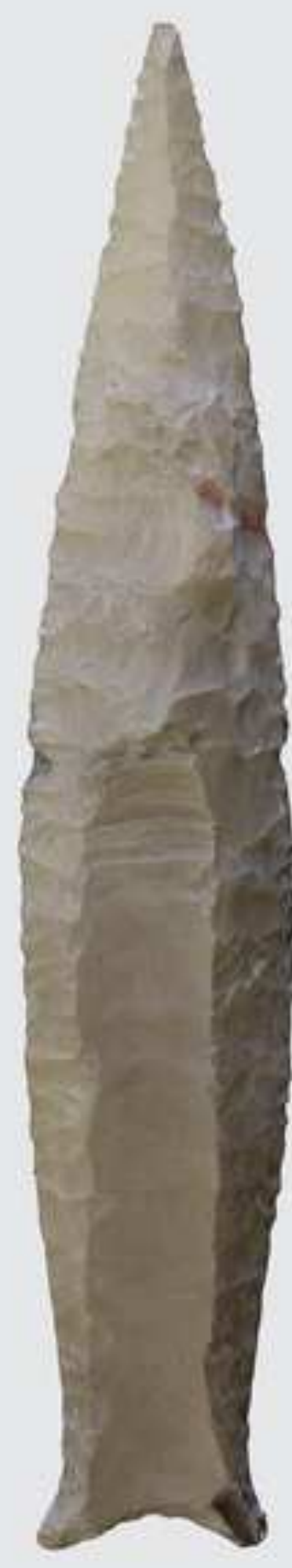

A

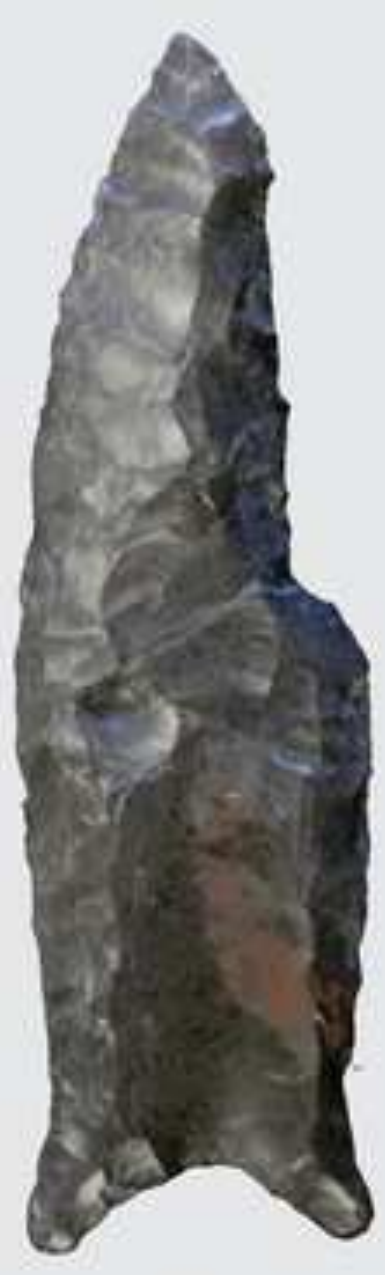

B
$\underset{0 \mathrm{~cm}}{\bigsqcup}$
2.5
5.0

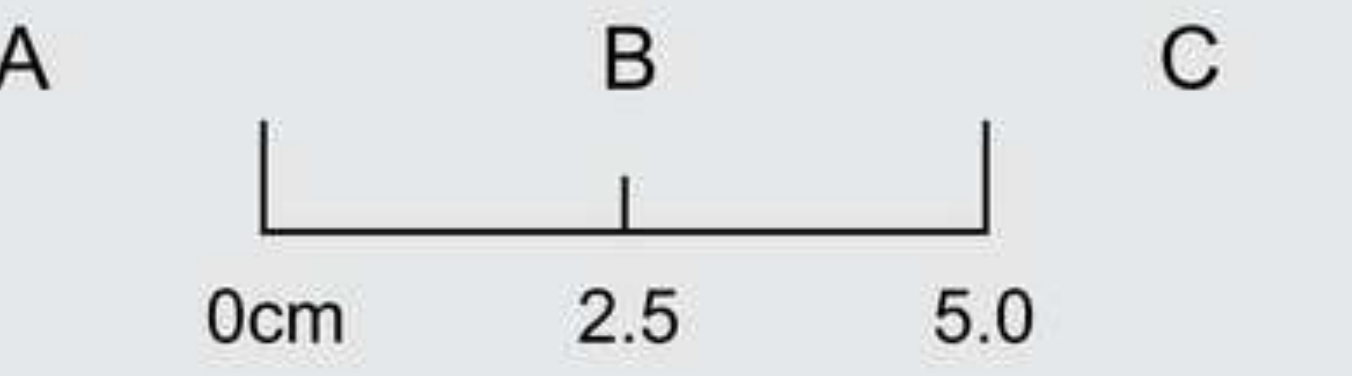

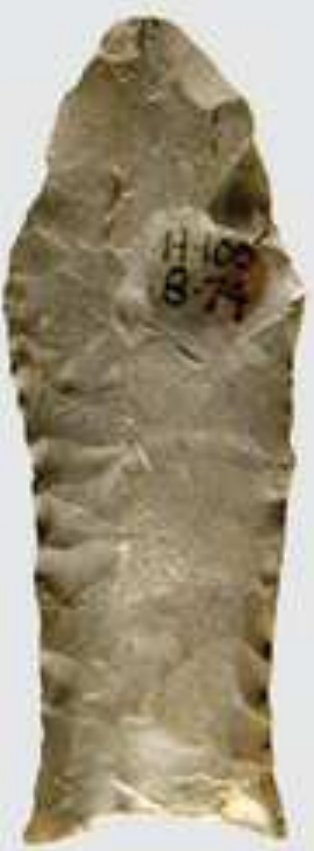

C 


\section{Frequencies in Length of Complete Bifaces and Basal Fragments}

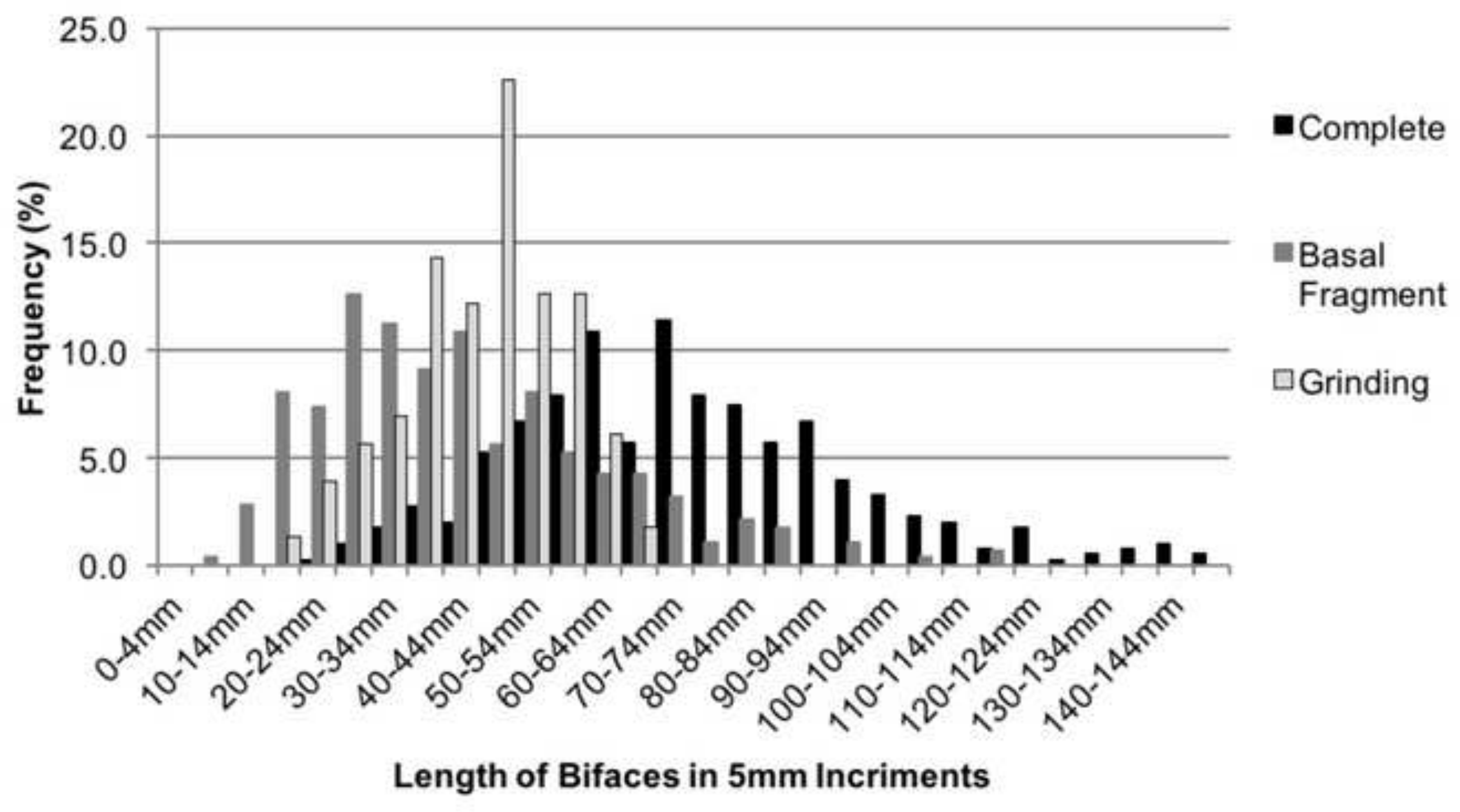

